\title{
TEORIDE VE UYGULAMADA KATMA DEĞER VERGİSİ
}

\section{Numan öZSOY}

\section{Teoride Katma Değer Vergisi}

\section{A. Katma Değer Kavrami:}

Katma değer vergisi adından da anlaşılacağı üzere, vergilemede katma değeri esas olan bir vergidir. $\mathrm{O}$ halde önce, katma değer kavramının açıklığa kavuşturulması gereklidir.

Katma değeri (Value added veya valeur ajoutèe) bir mal ve hizmet üretimi faaliyetinde üretime katılan iktisadi faktörlerin yarattıkları ek değer olarak tanımlamak mümkündür. Uretim faktörlerinin yarattıkları bu ek değerlerin toplamı bize, milli ekonomi bakımından, milli geliri (NNP) veya gayrisafi milli hasılayı (GNP) verir. Üretim faktörlerine, ödenen paylar ise bilindiği üzere, kâr, faiz, kira, ve ücrettir, Bu payların toplamı bize yine milli geliri verecektir. Demek oluyorki katma Değer, ülke itibariyle milli gelirdır. Bu nedenle katma Değer vergisine, (dolaylı gelir vergisi) de denmektedir.

Yukanda açılamadan anlaşılacağı gibi, firma seviyesinde, katma değeri iki yoldan hesaplamak mümkündür:

(1) Toplama metodu

(2) Çıkarma metodu,

1) Toplama metodunda, üretim faktörlerine ödenen, kâr, ücret, faiz ve kira toplanır. Kâr, aynen gelen Vergisi bakımından hesaplanan miktardır. Yukarıdaki kâr, amortisman düşülmeden hesaplanmısssa, bu paylar toplamı (faktör fiyatları tle gayrisafi katma değerdir.) Buna dolayı vergiler eklenirse (piyasa fiatları ile gayrisafi Katma Değer) elde olunur. Amortisman payı ve dolaylı vergiler, düşüldükten sonra hesaplanan katma değer ise «faktör fiatlanı ile net katma değerdir.» 
2) Çıkarma metodunda ise üretim değerinden mal ve hizmet alışlan düşülerek katma değer bulunur. Bir döneme ait üretimin tümü satılmışsa, bu satıştan, üretimin tamamı satılmamışsa, satışlarla stok artış toplamından alışlar düşülmek suretiyle katma değer hesaplanabilir.

Çıkarma ve Toplama metodunda katma dcğerin hesaplanış şekli aşağıdaki örnekte daha iyi görülebilir.

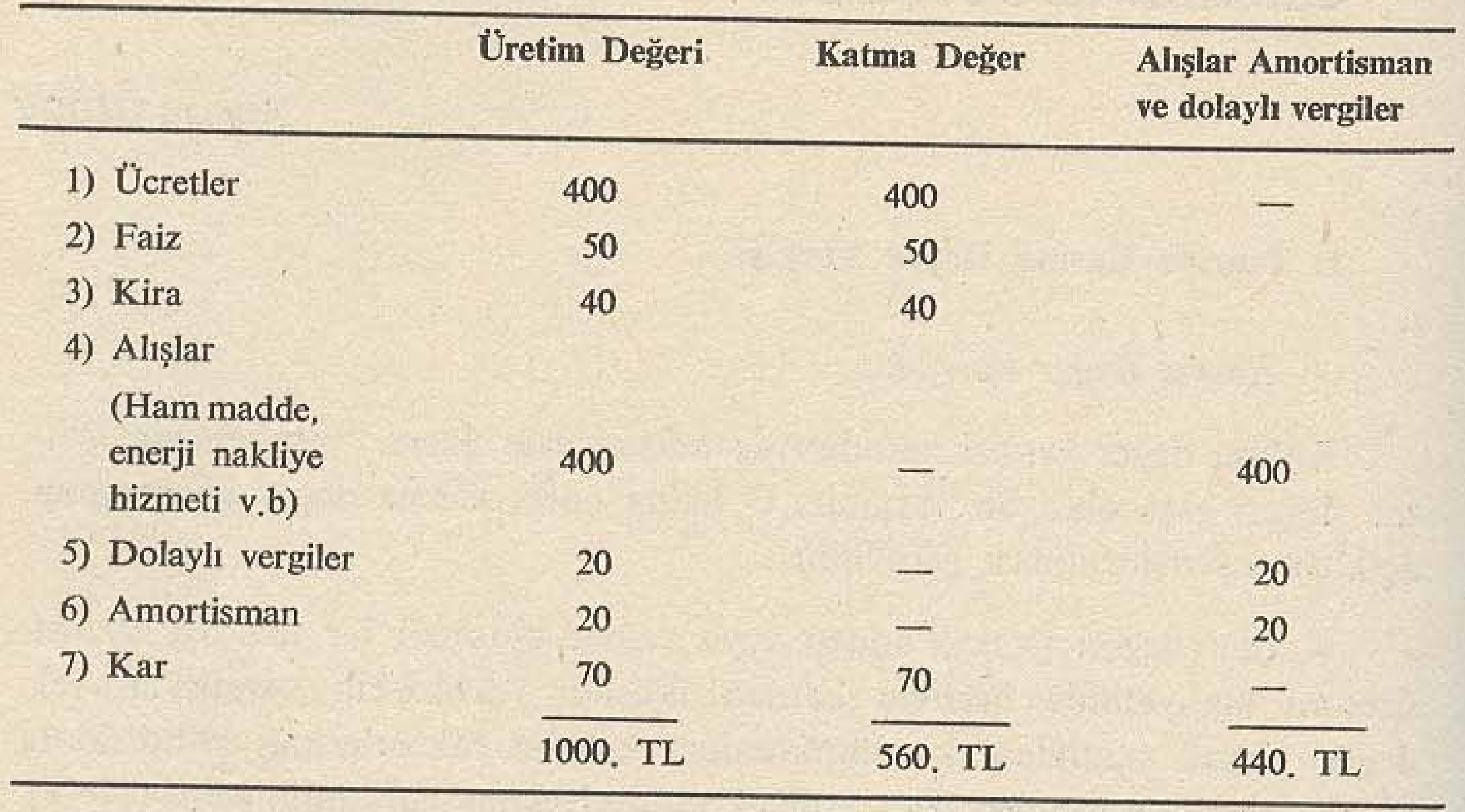

Yukarıdaki Tabloda üretimin değeri (satış fiatı ile) 1000.TL dir. Toplam maliyet olan 930 lira içinde, alışlar, dolayı vergiler, amortisman ve faktör paylarına ödenen ücret, faiz, kira vardır. Görüleceği üzere, Satıslar ile maliyet arasindaki fark bize katma değeri vermeyip sadece kârı vermekmektedir. Katma değer ise, çıkarma metodu ile hesaplanacak olursa, satış bedelinden alışlar, dolaylı vergiler ve amortisman payının düşürülmesinden sonra kalan miktardır. Yani $1000-440=560$ TL.dır. 560-liralık katma değer ise, «Toplama metodu ile» üretim faktörlerinin paylarının toplanması suretiyle de bulunabilir.

Yukarıdaki tabloyu daha yakından inceleyecek olursak 560-liralık katma değerin, faktör fiatlan ile net Katma Değer «olduğunu görürüz. Faktör fiatları ile gayrisafi katma değer ise, amortisman payı olan 20-liranın eklenmesi ile 580 lira olarak bulunacaktır. Dolaylı vergileri düşmezsek, piyasa fiatları ile gayri safi Katma Değeri» 600-lira olarak hesaplıyabiliriz.

Yukarıdaki tablo da, üretim değerinden düşülen alışlar sadece, hammadde enerji gibi üretilen malın bünyesine giren değerlerdir. Oysa, aynı üretim için, amortismana tabi bir iktisadi sabit kuymet alınmış olabilir. Örneği- 
mizde, bu sabit kıymetin sadece amortisman payı düşülmüştür. Örnegimizdeki katma değer, bu nedenle gelir tipi olarak adlandırılır. Eğer amortisman payı yerine, alınan sabit değerin bir başka ifade ile yatırımların tüm değeri düşülürse bu takdirde, gelirtipinden uzaklaşmış ve «Tüketim tipi» olarak adlandırılan Katma değerı bulmuş oluruz. Katma değeri hesaplarken, amartisman payını düşmezsek, «gayrisafi gelir tipi» «gros product» Katma değeri elde ederiz.

Gelirtipi katma değer üzerinden alınan vergi, dolaylı bir gelir Vergisi mahiyetinde olduğu halde, tüketim tipi Katma değer üzerinden alınan vergi, bu özelliğini kaybetmektedir.

Buraya kadar, Katma değer kavramını açıklamaya çalışık. Ancak katma değerin hesabı vergileme yönünden daha farklı ve basit olmakta, daha doğru bir ifade ile, katma değer üzerinden alınacak vergi için katma değerin hesaplanmasına bile lüzum kalmamaktadır. Bu durum ileriki bölümlerde daha ayrıntılı bir şekilde açıklanmıştır.

\section{B) Katma Değer Vergisinin Mahiyeti ve Çeşitli Vergiler İ̧̧indeki Yeri:}

Katma Değer Vergisi bir satış vergisidir. Zira Vergi satı̧̧ bedeli üzerinden alınır. O halde, satı̧s bedeli üzerinden alınan bu vergi, neşekilde katma değeri vergilemiş olmaktadır? Bu sorunun cevabını vermeden önce Katma Değer Vergisinin satış vergileri içindeki yerini belirtmek gereklidir.

Bilindiği üzere vergiler genellikle üç ana konu üzerinden alınmaktadır.

(1) Gelir

(2) Servet

(3) Gelir veya servetten yapılan harcama

Gelir üzerinden alınan vergiler, gelir ve kurumlar vergileridir.

Servetten alınan vergiler ise, veraset ve intikal vergisi, Emlâk vergisi, gayrimenkül kıymet artışı vergisi gibi vergilerdir.

Bir kişi bir dönem itibariyle elde ettiği gelirin bir kısmını harcar, bir kısmını da tasarruf eder. Tasarruf edilen gelir yatırıma tahsis ediler ve bu yatırım, müteakip dönemlerde servete dönüşür. Şu halde bir kimsenin gelirini müterakki bir gelir vergisi ile vergileyebilirsek, Vergiden beklenen mali, ekonomik ve sosyal amaçlara en uygun bir vergilemeyi yapmış oluruz. Ancak, uygulamada bu gayeyi, tek başına geliri vergilemekle elde etmek de her zaman mümkün değildir. Gelirin bu gayeye uygun vergilene- 
bilmesi için, onun diğer vergileme araçları ile desteklenmesi gereklidir. Zira, gelir vergisinde sosyal ve ekonomik amaçlarla konulan istisna ve muafiyetler, vergiyi malî amacı gerçekleştirmekten uzaklaştırdığı gibi, diğer gayelerinde tam gerçekleşmesini engellemiş olur. Servet üzerinden sosyal amaçla alınan vergiler, sosyal gayeyi desteklemeye yönelmiştir. Harcamalar üzerinden alınacak vergiler ise, daha ziyade gelir vergisiyle gerçekleştirilemiyecek gayelerin elde edilmesine yardımcı olmak bakımından önem taşılar. Kişinin gelir vergisi ile kavranamıan mali gücünü servet veya gelirinden yaptığı harcamayı vergileme yolu ile kavrayabilıriz Kaynakta tevkif veya "peşin ödeme,, usulünün tatbik edilmediği hallerde, gelir vergisinin, ekonomide, talep idaresinin bir aracı olarak kullanılması olanağı zayıftır. Bu olanak, harcama veya satı̧ vergileri ile elde edilmiş olur. Harcama dolayısiyle satışlar üzerinden alınan vergiler bu nedenle vergilemeden beklenen amaçları gerçekleştirme de gelir vergisini destekleyen, ona yardımcı olan vergileridr. Bir satış vergisinin bu fonksiyonunu ifa edebilmesi, onun hangi şekilde ve tipte uygulandığına bağıdır. Kapalı bir ekonomi düşünüldüğünde, satış vergilerinin de genellikle iki çeşit olduğu görülür.

\section{Satış Vergileri:}

(1) Yayılı (çok safhalı, şelâle "cascade tipi») vergiler

(2) Toplu (Tek safhah) vergiler.

Bir mal, üretim ve dağıtım ameliyesi süresince, üreticiden tüketiciye kadar bir çok safhalardan geçerek tüketiciye intikal eder. Bu safhalar,

$$
\begin{aligned}
& \text { Üretici - tüketici } \\
& \text { Üretici - Perakendeci - Tüketeci } \\
& \text { Üretici - Toptanci - Perakendeci - Tüketici } \\
& \text { Üretici - Satış temsilcisi - Perakendeci - tüketici } \\
& \text { Üretici - Satış temsilcisi - Perakendeci - tüketici şekillerinde }
\end{aligned}
$$

olabilir. Bunlar arasında en çok görüleni üretici — toptancı - perakendeci - tüketici şeklinde olanıdır. Bu şekle göre vergileri adlandırmak gerekirse, her safhada alınan vergiler yayılı, geniş, tabanlı, çok safhalı satıs vergileri olarak adlandırılır. Vergi, malın üreticiden toptancıya veya perakendiciye intikalinde alınıyersa ilk safhada alınan teksafhalı veya toplu satı̧ vergisi olarak adlandırılır. Yalnızperakendeciden tüketiciye 
satışta alınan bir vergi de tek safhalı bir satış vergisidir. Vergi hangi safhada alınıyorsa ona göre de isim alır. İstihsal vergisi, toptancı satış vergisi, perakendeci satış vergisi gibi. Bizim uygulamamızda istihsal vergisi tek safhalı, toplu bir satı̧ vergisidir. İşletme vergisi tek safhalı perakendeci satı̧̧ vergisidir. tedir?

Katma Değer vergisi, yukarıda belirtilenlerden hangisine girmekte-

Katma Değer Vergisi, teoride ve uygulamada, çok safhalı yayılı bir satış vergisidir. Ancak şelale tipi «cascade» satı̧s vergisinden vergi mükerrerliğini önleme ve matrah yönünden ayrılır. Aşağıdaki tabloda bu fark gösterilmiştir. (Vergi oranı \% 10) olduğuna göre)

\begin{tabular}{|c|c|c|c|c|c|}
\hline & $\begin{array}{l}\text { Vergi hariç } \\
\text { satış değeri }\end{array}$ & $\begin{array}{r}\text { Cascade } \\
\text { tipi vergi }\end{array}$ & $\begin{array}{l}\text { Perakende } \\
\text { satış vergisi }\end{array}$ & $\begin{array}{l}\text { Vergi hariç } \\
\text { Katma değer }\end{array}$ & $\begin{array}{c}\text { Katma } \\
\text { değer vergisi }\end{array}$ \\
\hline İmalatcı & $100-\mathrm{TL}$ & 10 & - & 100 & 10 \\
\hline Toptanci & $125-\mathrm{TL}$ & 13,50 & - & 25 & 2,5 \\
\hline Perakendeci & 200-TL & 21,35 & 20 & 75 & 7,5 \\
\hline $\begin{array}{l}\text { Malın rihaî } \\
\text { Değeri }\end{array}$ & $200 . T L$ & - & - & 200 & - \\
\hline $\begin{array}{l}\text { Toplam vergi } \\
\text { yükü }\end{array}$ & - & 44,85 & 20 & - & 20 \\
\hline
\end{tabular}

Yukarıdaki tabloda cascade şelale tipi vergi ile, katma değer vergisi ve tek safhalı bir vergi (perakende satış vergisi) görülmektedir. İmalâtçı safhasında üretilen 100-liralık malın alışının (0) olduğu farz edilmiştir. Görüleceği üzere, Katma değer vergisi, matrah yönünden, şelale tipi vergiden ayrılmakta ve vergi üzerinden vergi alınması söz konusu olmamaktadır. Oysa şelale tipi satış vergisinde matrah satı̧ bedeli olup, bir evvelki safhada alınan vergi de bu matraha eklenmekte ve nihai değeri 200 lira olan bir malın vergisi \% 10 nispeti ile 44,85 lira yükselmektedir? Katma değer vergisi ise toplam Katmadeğer üzerinden sadece 20-liradır.

Katma Değer Vergisi ile Perakende satı̧ vergisi arasındaki fark, birinin tek safhada, diğerinin çok safhada alınmasıdır. Vergi miktarı her ikisinde aynıdır. Perakendeci safhasında, vergi bir kerede alındığı halde, katma değer vergisinde, verginin tahsili bir önceki safhalarda da yapılmaktadır. Bu nedenle, Katma Değer vergisine, vergi tahsilâtı bir önceki safhalarda da yaptlan perakendeci satıs vergisi denmek te mümkündür. 
Perakendeci satıs vergisinin, tam aksi ilk üretim veya imalât safhasinda alınan istihsal vergisidir. Ilk safhada alınan bu tip verginin, matrahı, perakendeci satış vergisinden tabiatiyle düşüktür. Dolayısı ile, ayni geliri sağlamak için vergi oranının istihsal vergisinde, gerek perakende satış vergisi gerekse katma değer vergisi oranından yüksek olması gereklidir.

Katma Değer Verğisinin mahiyetinin daha iyi anlaşılması için onun tiplerini bilmek gerekmektedir. Müteakip bölümde Katma Değer kavramına peralel olarak verginin tipleri açıklanmıştır.

\section{C) Katma Değer Vergisinin Tipleri:}

Katma değer vergisi, bir teşebbüsün, diğer tesebbüslerden aldığı mallara teşebbüs ve işgücü veya sermayesi ile eklediği değer üzerinden alınmaktadır. Teşebbüsün diğer teşebbüslerden aldığı mallar, ham maddeler veya sermaye mallarıdır. Sermaye mallarının alıs bedellerinin, satış bedellerinden indirilme şekline göre katma değer vergisi tiplere ayrılır

\section{1) Gayrisafi hasla tipi K.D.V. (gross product VAT)}

Bu tip katma değer vergisinde sermaye mallanı dışındaki ahışlar satış bedelinden indirilerek, katma değer veya vergi matrahı hesaplanır. Sermaye ve yatırım malları, amortismana tabi iktisadi kiymetler olup, bir işletmede bir yıldan fazla kullanabilen değerlerdir. Bina, makina, teçhizat, mobilya gibi. Milli gelir, bilindiği gibi, kapalı bir ekonomide (yani ithalat ve ihracatın olmadığı farzedilirse) harcama yönünden yatırım ve tüketim mallarına yapılan harcamalardan ibarettir. Bilinen formül şöyledir.

$$
\begin{aligned}
& \mathrm{Y}=\mathrm{C}+\mathrm{I} \\
& \mathrm{y}=\text { Milli gelir }=\mathrm{w}(\text { ücret })+\mathrm{p} \quad(\text { Kâr, kira })+\mathrm{D} \quad \text { (Amortisman) } \\
& \mathrm{c}=\text { Tüketim } \\
& \mathrm{I}=\text { Yatırım. }
\end{aligned}
$$

Denklemin her iki tarafına ara ve ham madde (hizmet dahil) alışlarını eklersek denklik bozulmuyacaktır.

Ara ve Ham maddeleri (A) ile ifade edersek denklemi şöyle yazabiliriz. ${ }^{1}$

$$
\mathrm{A}+\mathrm{Y}=\mathrm{C}+\mathrm{I}+\mathrm{A}
$$

\footnotetext{
1 Ara mallar açıklık vermek için yazılmıştır. Aslında $\mathrm{C}+\mathrm{I}$ formülü bize tüm satıșları verdıginden, ara malların Maliyeti dc yatırım ve tüketim malları malıyetine dahildır.
} 
$(A+Y)$ bize tüm üretimin satış fiatı ile değerini verir Bu bedelden ara ve ham madde alışlarını düşerek, Katma değer vergisi matrahı yine $\mathrm{Y}=\mathrm{C}+\mathrm{I}$, bir başka ifade ile (GNP) gayrisafi milli hasıladır. Bu matrah üzerinden alınan vergi ise gayrisafi hasıla tipi katma değer vergisidir.

\section{2) Gelir Tipi Katma Değer Vergisi:}

Gayrisafi hasıla tipi Katma Değer Vergisinde, satışlardan sadece, sermaye mallar ıdışındaki malların alış bedellerinin düşüldüğü belirtilmişti. Gelir Tipi'nde ise sermeya mallarının amortisman payı ara ve ham maddelerle birlikte dü̈sülür.

$$
\mathrm{Y}=\mathrm{W}+\mathrm{P}+\mathrm{D}=\mathrm{C}+\mathrm{I}
$$

vergilenecek matrah buna göre,

$$
\mathrm{C}+\mathrm{I}-\mathrm{D}=\mathrm{w}+\mathrm{P} \text { dir. }
$$

Böylece matrah, bir başka deyimle makro düzeyde milli gelir yani gayrisafi milli hasıladan amortisman payı düşülmek suretiyle elde edilen safimilli hasıladir.

3) Tüketim tipi katma değer vergisi: Satış fiati ile üretim değerinden, sermaye malları dışındaki alı̧̧ların düşülmesi halinde, gayrisafi hasıla tipi Katma Değer vergisinin matrahının; bu matrahtan da, amortisman payının düşülmesi ile gelir tipi Katma değer vergisi matrahının elde olunacağını belirtmiştik. Eğer satış, bedelleri toplamından, ara ve ham maddelerle birlikte yatırım malları alışları yani tüm alışlar düşülürse, Tüketim tipi Katma Değer Vergisi matrahı elde olunur. Yani:

$$
\begin{aligned}
& \mathrm{A}+\mathrm{Y}=\mathrm{C}+\mathrm{I}+\mathrm{A} \\
& \mathrm{A}+\mathrm{Y}-\mathrm{I}-\mathrm{A}=\mathrm{C} \\
& \mathrm{Y}-\mathrm{I}=\mathrm{C}
\end{aligned}
$$

Görüleceği üzere tüketim tipi katma değer vergisinde, sadece tüketim, yani tüketim malları (hizmet dahil) satışları vergilendirilmiş olmaktadır. Bu tip katma değer vergisi anlaşllacağı gibi (genel istiblâk - Tüketim vergisi) niteliğindedir.

Buraya kadar açıklamalarımızda kapalı bir ekonomiyi düşündük. Yani ithalat ve ihracatın olmadığın farzettik. İthalât ve ihracat işlemlerinin olması halinde, milletlerarası ticarette katma değer vergisinin nasıl işlediğinin tetkiki önem arzeder. 


\section{D) Milletlerarast Ticarete Katma Değer Vergisi:}

Bu verginin son $10-15$ yıldır bukadar ilgi çekmesinin ve inceleme konusu yapılmasının nedeni, onun milletler arası ticaret bakımından arzettiğı önemdir.

Bilindiği gibi, Roma andalaşması ile 6 Avrupa ülkesi arasında, ekonomik entegrasyon hareketi başlamıştı. Ekonomik alandaki bir hedef, aralarında malların serbestçe mübadelesini sağlamak ve bunun için mevcut engelleri ortadan kaldırmaktı. Bu amaçla gümrük vergileri duvarı kaldırilmıștı. Ancak, vergi yönünden, gümrük vergilerini kaldırmak meselenin halli için kâfi değildi. Zira, ülke içinde uygulanan diğer vasıtalı vergilerin, gerek oran, gerekse matrah bakımından farkh oluşu, aralarındaki ticari rekabeti bozan ve malların eşit vergi yükü ile tedavüllerine olanak sağlamayan önemli bir unsurdu. Bu nedenle Avrupa Ekonomik Topluğu (AET) Konseyi, üye ülkelerin ortak bir muamele vergisine geçmelerini öngördü. AET nin öngördüğü ortak muamele vergisi ise Katma Değer Vergisi olmuştur. Katma Değer vergisinin ortak muamele vergisi olarak secilmesindeki en önemli neden, onun ticari muamelelerde, tarafsızlığı sağlamasıdır. Ortak pazarın hedefi, üye ülkeler arasındaki mübadelelerin hiç bir engel olmaksızın, bir ülkenin dahili piyasasında olduğu gibi yapılmasıdır. Bu nedenle ülkeler arasında malların aynı vergi yükünü taşıması ticari rekabeti bozmaması gerekmektedir. $\mathrm{Bu}$ amacın sağlanması için, milletlerarası ticarette Katma Değer Vergisi ya «Kaynak-origin) veya (... Destination) prensibine göre uygulanir.

1) Kaynak (origin) ilkesi: Bu prensibe göre, ihraç edilen mallar vergiye tabi olup ihracatta her hangi bir vergi iadesi veya muafiyet uygulanmaz. İhraç edilen bu malları, ithal eden ülke vergilemez. Eğer heriki ülkede Katma Değer vergisi oranı aynı ise aynen bir ülke dahili piyasasında olduğu gibi ticaret konusu mallar aynı vergi yükünü taşır.

2) Destinasyon (Destination) prensibi (varış) Destinasyon perensibine göre de milletler arası ticarete konu olan mallar ithal eden ülke tarafından ithal sirasinda vergilenir; İhraç eden ülke tarafundan vergilenmez.

Her iki prensibi sayısal bir örnekle gösterebiliriz. (A) ülkesinde imal edilen bir mal ihracatçı elı ile (B) ülkesine ihraç edilsin. (A) ülkesinde bu mal imalatçısı tarafından (B) ülkesindeki ithalaţ̧ıyâ 150 liraya satılsın. (B) ülkesinde de ithalâtçı tarafından toptancıya 200 liraya toptancı tarafından da perakendeciye 240 liraya, perakendici tarafından da tüketiciye 310 lira ya satılsın. Her iki prensibe göre, Katma Değer Vergisi tahsilâtı A ve B ülkesinde şöyle olacaktır: (Vergi oranı \% 10 olduğuna göre) 


\begin{tabular}{lcccc}
\hline & \multicolumn{2}{c}{ Kaynak prensibi } & \multicolumn{2}{c}{ Destinasyon prensibi } \\
& A & B & A & B \\
\hline İmalatcının satıșı & $10 \mathrm{TL}$ & - & 0 & - \\
Ihracatçının satıșı & 5 & $\ldots$ & 0 & - \\
İthalat & - & 0 & - & 15 \\
Ithalatcının satıșı & - & 5 & - & 5 \\
Toptancının satıșı & - & 4 & - & 4 \\
Perakendecinin satıșı & - & 7 & - & 7 \\
\hline \multicolumn{1}{c}{ Toplam } & 15 & 16 & 0 & 31 \\
\hline
\end{tabular}

Destinasyon prensibine göre ihraç eden ülke (A) ihraç edilen mallardan hiç bir vergi almamaktadır. (A) ülkesinde, imalâtçının satışı vergilenmekte ise de ihracatçı, kendisine fatura edilen bu vergiyi geri aldığından vergi yükü yine $(O)$ olmaktadır. İthal eden ülke yaratılan değerler üzerinden 31 lira vergi alacaktır. Orginin (Kaynak) prensibine göre ise, ihraç edilen ülkede yaratılan katma değer vergilenmekte, ithal eden ülkede, ise destination prensibinin aksine sadece ithal edildikten sonra yaratılan katma değer vergilenmektedir. Böylece ithal eden ülkenin vergi tahsilatı (Origin prensibine geçişte) $31 \mathrm{TL}$. den 16 liraya düşmekte, ihraç eden ülkenin hasılatı ise (0) dan 15 liraya yükselmektedir. Görüleceği üzere, ithalâttaki vergi yükü ile tüketiciye intikal eden vergi her iki prensipte ayn olmakla beraber, iki ülkede tahsiledilen vergi miktarında farklılıklar olmaktadır.

\section{II) Katma Değer Vergisinin Hesaplanması:}

Katma değerin hesaplanmasında, toplama ve çıkarma metodlarından sözetmiştik. Oysa katma değer vergisinin hesaplanmasında üç metod vardır. Bunlar Toplama, Çıkarma ve vergi indirimi, metodlarıdır. Bunları biraz daha açıklamada yarar vardır.

\section{A) Toplama Metodu:}

Katma Değeri üretim faktörlerine ödenen paylar toplamı olarak tanımladığımıza göre, gelir tipi katma değer vergisi, üretim faktörlerine ödenen ücret, faiz kira ve kâr toplamı üzerinden, bir orana göre hesap edilir. Bır işletmede, işçilerin ücreti, ödenen faiz ve kira bellidir. Kar, gelirtipi katma değerde, aynen gelir vergisin de olduğu gibi amortisman payı düşülmek ve yılbaşı ve sonu stokları nazara alınmak suretiyle hesaplanır. 
Gayrisafi hasıla katma değer vergisinde kar, amortisman payı düşülmeden brüt olarak vergi matrahına dahil edilir.

Tüketim tipi katma değer vergisinin hesabı için toplama metodu pek elverişli olmamaktadır.

\section{B) Çıkarma Metodu:}

Çıkarma metodunda verginin matrahı, satış bedelleri toplamından, alışlar düşülmek suretiyle bulunur.

Sadece yatırım mallan dışındaki alışlar düşülürse, gelir tipi katma değer vergisinin matrahı elde edilir. Alışların tamamının düşülmesi halinde tüketim tipi katma değer vergisinin matrahı bulunur.

Gayri safi hasıla tipi katma değer vergisinin matrahın bulmak için gelir tipi katma değere amortisman payının eklenmesinin gerekeceği tabidir.

\section{C) Vergi Indirimi Metodu:}

$\mathrm{Bu}$ metod çıkarma metodunun bir nevi olup, bu metoda vergiden verginin indirimi demek daha uygundur. Zira, bu metoda göre, katma değer vergisi; satış bedeli üzerinden hesaplanan vergiden, alış faturasında gösterilen verginin indirilmesi suretiyle hesap edilir.

Yatırım malları dahil bütün alışlara ait vergilerin, satış bedeli üzerinden hesaplanan vergiden indirilmesi ile, tüketim tipi katma değer vergisi hesaplanmış olur.

Yatırım malları hariç diğer alışlara ait vergiler hesaplanan vergiden indirilirse, gayri safi hasıla tipi katma değer vergisi bulunur.

Eğer satı̧ vergisinden yatırım mallarına ait amortisman payına ve diğer alışlara ait vergiler düşülürse gelir tipi katma değer vergisinin hesaplanması mümkün olur. Ancak görüleceği üzere vergi indirimi metodu, daha ziyade tüketim tipi verginin hesaplanmasina daha uygun olmaktadır.

\section{III) Uygulamada Katma Değer Vergisi}

Buraya kadar, Katma Değerin ve Katma Değer vergisinin tipleri ve hesaplanış şekillerınden söz ettik.

Bunların bazılarının uygulanmasında güçlükler olacağı tabidir. Ancak. bu vergi uygulamada son derece basit ve kolay bir şekilde yürütülmektedir. Bunun nedeni Katma Değer vergisinin, Tüketim tipi olarak ve vergiden verginin indirilmesi metodu ile uygulanmasıdir. 


\section{TEORIDE VE UYGULAMADA KATMA DEGER VERGISI}

Gercekte AET Konseyi, Katma Değer vergisini, bu basit ve kolay şekli ile üye ülkelerin uygulayacakları ortak bir muamele veya satıs vergisi
olarak kabul etmiştir.

\section{A) AET Modeli (Ortak Pazar Ortak Katma Değer Vergisi Sistemi)}

Katma Değer kavramlı Vergiler daha önce gerek pratikte, gerekse teoride, yeri olmakla beraber Katma Değer vergisi ilk defa Fransada 1955 yilındanitibaren, geniş uygulama alanı bulmuştur.

Ortak pazara üye olan ülkelerin vergilerinin ahenkleştirilmesi söz konusu olduğunda, Fransız modeli esas alınarak üye ülkelerin en geç 1.1.1972 tarihine kadar katma değer vergisine geçmeleri öngörülmüş ve Ortak pazar (AET) konseyi 11. Nisan 1967 tarihli ve 1 ve 2 numaralı Direktifleri ile uygulanacak katma değer vergisinin genel prensiplerini tesbit etmiştir. Bu direktifler, katma değer vergisinde mevzu, vergiyi doğuran olay, mükellef, matrah ve muafiyet gibi kanun tasarısinin hazırlanmasına ve uygulanmasina esas olacak ilkeleri ve tanimlamaları belirlemektedir.

Ortak pazar ülkeleri için kabul edilen bu ilkelere göre verginin işleyişi aşağıda belirtilmiştir.

1) Verginin mevzuu ve vergiyi doğuran olay:

Katma Değer vergisinde verginin mevzuu ve vergiyi doğuran olay malların teslimi ve hizmetlerin ifası ile malları ithalidir.

Malların ithali vergilenmiş olmakla Ortak pazar destination (Varış ülkesinde vergileme) prensibini kabul etmiş demektir. Ancak, Ortak pazarın hedefi, üye ülkeler arası ticarette origin (çıkıs ülkesinde vergileme) prensibini uygulamaktır.

Uye ülkeler kendi özelliklerine göre mevzu maddesinin kapsamının dışına bazı faaliyetleri çıkarabilirler. Genellikle tarım faaliyetleri bazı hizmetler, Banka ve Sigorta hizmetleri vergiden istisna edilmektedir. Ancak tarım faaliyetlerinin ne şekilde vergileneceği konusundaki esasların tespiti çalışmaları yapılmaktadır.

İhracat muaftır. Bu, «destination,» ilkesinin bir gereğidir.

Keza ülkeler, perakendeci safhaya bu vergiyi uygulamakta, Konseyin önceden iznini almak şartıyla muhtardırlar. İstisna, muafiyet pek az uygu- 
2) Verginin mükellefi

Verginin mükellefi vergiye tabi muameleleri ticari veya mesleki faaliyet çerçevesinde ifa edenlerdir. Ithalde mükellef, ithalatı bilfiil yapandır.

3) Matrah:

Ortak pazar vergi modelinde, verginin matraht satış bedelidir. Matrah katma değer değildir. Bu nokta son derece önemlidir. Zira katma değerin hesaplanması ayrı, verginin hesaplanması ayrı bir husustur. Katma Değer hesaplanmasına gerek kalmadan da vergi hesaplanabilir. Bunu sağlıyan, vergiden verginin indirilmesi usulüdür.. Ortak pazarın sectiği tüketim tipi ve vergi indirimi usulü bu nedenle uygulamada kolaylık ve basitlik sağlamaktadır. Karışık ve güç bir muhasebeye gerek yoktur. İşletme hesabı usulüne göre defter tutan hergelir vergisi mükellefi bunu yapabilir. Bütün iş alıştaki vergileri, satı̧ bedeli üzerinden ve faturada gösterilen vergileri ayrı ayrı (bir dönem itibarı ile) yazıp, satıştaki vergi ile alıştaki vergi arasindaki farkı hazineye ödemekten ibarettir.

Oysa Katma Değer Vergisi hakkında çıkan bazı yazılarda bunun muhasebesinin, çok güç olduğu, mükelleflerin bilgili veya bu işi bilen elemanlara ihtiyacı olacağı ileri sürülmektedir. Bu görüş, yukarıda bahsettiğimiz usul için tamamen yanlıştır. Mevcut dünya tatbikatı incelenmeden bu şekilde sorumsuzca yazılan yazılar vergi hakkında yanlış kanaatlerin doğmasına sebep olabilmektedir.

\section{4) Vergi İndirim ${ }^{1}$ Usulû:}

AET konseyi, ortak pazar için vergiden verginin indirilmesi usulünü benimsemiştir. $\mathrm{Bu}$ usulde katma değerin ayrıca besabına gerek yoktur. Ancak sonuçta katma değer üzerinden vergi hesaplanıp ödenmiş olmaktadır. Aşağıda birmalın üretimden tüketiciye kadar intikali sırasında vergilenme durumu gösterilmiştir.

Vergi Oran $\% 10$

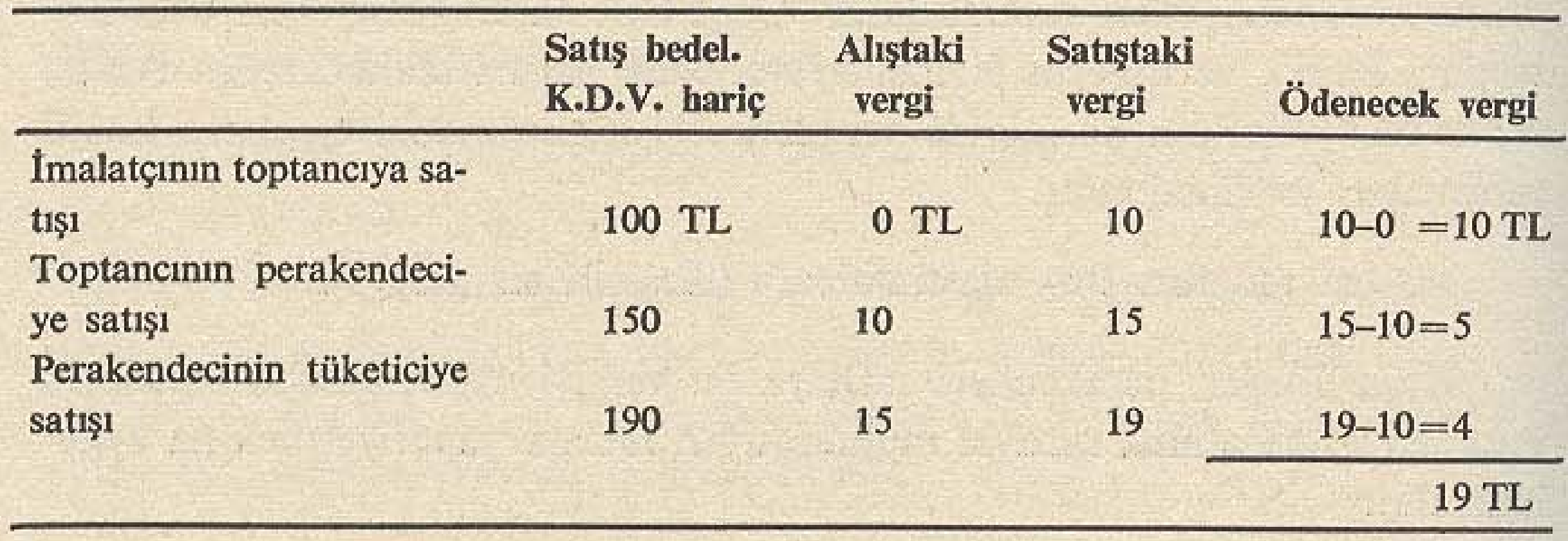


İmalatcının alışının (0) olduğu, dolayısiyle alıştaki verginin (0) olduğu varsayımı yapılmıştır. İmalâtcının satış faturasında satış bedeli vergi hariç 100, vergi dahil 110-lira görünecektir. Ancak vergi faturada ayrı olarak gösterilmiştir.

Toptancının alış bedeli vergi dahil 110 -liradır. Toptancı 50-lira bir ekdeğer ilavesi ile satarsa, satış faturası şöyle tanzim edilecektir:

Satı̧ bedeli : 150

$\% 10 \mathrm{KDV}: 15$

Toplam fatu-

ra bedeli : $165 \mathrm{TL}$.

Toptancının Defter ve hesaplarına şöyle geçer:

Alışta :

Mal Hesabı : 100 TL

Vergi Hesabı 10

Kasa H. $\quad 110$ TL.

Satışta :

Kasa H. : $165 \mathrm{TL}$

Mal hesab1 : $150 \mathrm{TL}$

Vergi hesabı: $15 \mathrm{TL}$

Verginin Mal.yeye Ödenmesi :

Vergi hesabı: $5 \mathrm{TL}$

Kasa hesabi: 5 TL

Mükellef Maliyeye böylece 5 lira ödeyecektir.

(T) ile gösterirsek :

$\frac{\text { Kasa Hesabı }}{165(2) \mid \begin{array}{r}110(1) \\ 5(3)\end{array}} \frac{\text { Mal Hesabı }}{\text { (1) } 100 \mid 150 \text { (2) }} \frac{\text { Vergi Hesabı }}{\text { (1) } 10 \mid 15 \text { (2) }}$

Perakendeci Malı K.D.V. si Hariç $150 \mathrm{Tl}$ ye almıştır. Buna 40 liralık bir değer katarak satarsa satış bedeli üzerinden 19 lira vergi tahakkuk ettirecek, ancak alış faturasında 15 lira görüldüğünden $19-15=4 \mathrm{Tl}$ yi maliyeye ödeyecektir.

Indirilecek vergi ancak alış faturasında aynca gösterilen vergidir. Alınan malın vergiden muaf olması halinde, veya verginin faturada gösterilmemesi halinde vergi indirimi söz konusu değildir. 
İdirilecek vergi, satıștaki vergi miktarından Fazla olursa, fark ya müteakip döneme ait beyannamede indirilir veya maliyece mükellefe iade olunur.

Satı̧̧ vergiden muafsa her hangi bir vergi indirimi yine söz kor «usu değildir. $\mathrm{Bu}$ nedenle, alıştaki vergi mükellefin uhdesinde kalacağından, muafiyet bazen, vergiye tabi olmaktan daha avantajlı olmamaktadır.

Satışların bir kısmı muaf, bir kısmı vergiye tabi ise, alıştaki vergilerin indirilmesi, vergiye tabi satışların genel satışa oranlanması ile bulunacak bir orana göre yapilır. Buna «prorata» usulü denir.

\section{5) Vergi Oranı:}

AET Konseyi vergi oranının ne olması gerektiği hususunda bir direktif vermemiştir. Ancak, dahilde ve ithal de uygulanacak oranların ayni olmasını keza, mallarla hizmetlere ayni oranın uygulanmasını öngörmüştür. Vergi oranının tek olması idealdir. Ancak normal oranın altında ve üstünde indirimli veya zamlı birer oran tesbit olunabilir.

6) Vergilendirme Dönemi:

Vergilendirme dönemi bir aydır. Yani bir ay içinde yapılan satışların vergileri toplanır. O aya ait alışların vergileri de toplanır. Aradaki fark muteakip ayda ödenir.

Vergilendirme dönemi 3 ayda olabilir.

Götürü vergilendirmede, dönem 1 yıldır.

\section{7) İhracatta Vergi İdaesi}

AET konseyinin ikinci direktifinin 10 uncu maddesi, ihraç olunan mallarla ihracata ilişkin hizmetlerin vergiden muaf olmasını öngörmüştür. Ayrıca ihraç olunan Malların girdilerine ait vergiler de iade olunacaktır. Bunun için kanunda özel bir hüküm olmak gerekir. Aksi halde muaf vergi indirimden yararlanamazdı. Bazı ülkeler ihracata (0) nispeti uygulamak suretiyle, vergi indirimine ve iadesine imkan vermektedirler. Diğer iki halde de girdilere ait vergiler alı̧ faturasında görüleceğinden mahsup veya iade kolayca yapilabilmektedir.

8) Vergi muafiyetinden feragat:

Katma Değer vergisinde ideal olan bütün muamelerin vergiye tabi olmasıdır. Ancak, bazı nedenler ve ülkenin özellikleri gereği bazı muamele- 
lere veya bazı gerçek veya tüzel kişilere muafiyet tanınır. Ancak vergiden muafiyet vergi yükünden kurtulma anlamına gelmez. Bunu bir örnekle açıklıyalım: Bir ekmek fırınına vergi muafiyeti tanındığını düşünelim. Bu durumda ekmek fırını işletmesi ekmek satışlarında vergi ödemiyecek, katma değer için defter ve vesika düzenlemiyecektir. Ancak bu ekmek fırını işletmesi elektrik havagazı un, su, kömür, odun gibi girdileri dolayısı ile alıs faturalarında, satıcıya vergi ödemiştir. Girdilerin \% 10 oranında; satışlarun!n da zaruri gida maddesi olması nedeni ile indirimli $\% 7$ oranında vergiye tabi olduğunu farzederek 1000 liralık alışta satıcıya 100 lira vergi ödeyecek,

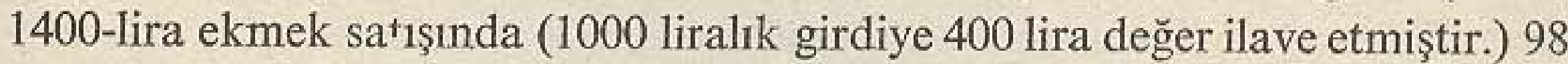
lira vergi tahakkuk ettirecek, fakat vergi indirimi daha fazla olduğundan Maliyeye bir vergi ödemiyecekti. Aksine 2 lira vergi iadesi alacaktı. Böylece vergi yükü, satışının vergiye tabi o'ması nedeni ile 100 lira yerine 98 lira olacaktı. Oysa vergiye tabi olmamakla vergi yükü 2 lira fazlası ile 100 lira olmaktadır.

Vergiden muaf olmanın mükellef yönünden başka bir sakıncası daha vardır. Oda bu muaf işletmelerden mal alacak olan vergiye tabi teşebbüsler muaf işletmeden alışlar dolayısı ile vergi indirimi hakkına sahip olmayacaklarından, bu muaf işletmeden mal alma yerine vergiye tabi müesseselerden mal almayı daha yararlı bulabileceklerdir.

$\mathrm{Bu}$ nedenlerle, kanunen vergi muafiyeti tanınan işletmelere muafiyetten feragat hakkı verilmiş bulunmaktad`r.

9) Götürü mükellefiyet.

Muafiyet defter tutma ve vesika düzenlemeden kurtulmayı sağlamakla beraber, bir önceki bentte belirttiğimiz gibi işletme bakımından bazı sakıncaları taşımaktadır. Bu nedenle küçük işletmelere her ay beyanname verme ve her satış için vesika düzenleme ye ine yillık olarak tesbit edilen matrah üzerinden götürü vergi verme olanağı sağlanmıştır. Götürü usule tabi mükellefler isteyen mükelleflere fatura vermek ve faturada vergiyi göstermek imkanına sahiptirler. Ayrıca alışlarına ait vergileri de, indirebilirler. Ancak götürü mükellefiyet hududunun geniş tutulması sistemin normal işlemesini aksatabilir.

10) Sisteme geçişte al:nması gereken tedbirler:

Mevcut sistemden, Katma değer vergisine geçişte yatırım malları ile stoktąki malların durumu önemlidir.

Tüketim tipi Katma Değer vergisinde, yatırım mallarına ait vergiler de indirileceğinden, Katma Değer vergisinin uygulanmasına kadar müteşeb- 
bisler yatırım malı alışlarını sıstemin uygulanmasına kadar geçiktirebilirler. Bu sebeple, geçiş döneminde, AET konseyi,

a) Vergi indiriminin taksitlerle yapılabileceğini veya,

b) Yatırım mallan için indirimlerin bir müddet yap lmayabileceğini,

c) veya vergi yürürlüğe girdiği zaman, henüz amortisman süresi tamamlanmamış yatırım malları için götürü bir indirim yapılabileceğini
önermiștir.

Ayni problem ticari stoktaki mallar için, de varittir. AET nim ikinci direktifinin 17 inci maddesi bu konuda da iade yapilabileceğini önermiş
bulunmaktadir.

Ancak, her ülkenin, bu geçiş döneminde, Katma Değer Vergisinin yerıni alacaği vergilerin durumuna göre gereken tedbirleri alacağ' tabiidir.

Katma Değer Vergisinin uygulaması ile ilgili özelliklerin hepsi burada belirtilmeyip, sadece önemlileri üzerinde durulmuştur.

\section{B) Türkiye Ve Katma Değer Vergisi}

Maliye Bakanlığı Gelirler genel Müdürlüğünce bu konuda bir tasarı hazırlanmış ve bir müddet önce ilgililere görüşleri alınmak üzere gön-
derilmiştir.

Tasarının gerekcesinde, Katma Değer vergisinin mahiyeti, işleyişi, ve önerilen hükümler hakkında gereken açıklamalar yapılmıştır.

Türk Katma Değer Vergisi, tabiatı ile, ekonomik ve sosyal gerçeklerimizle, vergi sistemimizin gerekleri ve bu alandaki teçrübelerimiz göz önünde bulundurularak ele alınmıştır.

Gerçekten Türkiye, satı̧ ve muamele vergileri alanında uzun bir tecrübeye sahiptir. Hattâ Katma Değer Vergisine benzer vergiyi ilk uygulayanlar arasında Türkiye de sayılmaktadır. Nitekim 1957 yılından önceki muamele vergisi tüm imalatı kapsamına alan, ve götürüde olsa iptidai madde indirimi ile imalatta katma değeri vergileyen bir sistemdi. Daha önceleri muamele vergisi toptancı safhasın da kapsamına alıyordu.

3843 sayılı muamele vergisi kanununun götürü indirim yerine faturadaki verginin gerçek usulle indirilmesi kabul edilseydi, bugünkü katma değer sistemine çok yakın bir sistemden kolaylıkla geçilebilirdi. Oysa 1957 yılında tam bunun aksi yapılmıs ve ilk istihsal maddelerine dayalı, istihsal vergisi sistemine geçilmiştir. O günün şartları bugün için çok değişmiş ve 
istihsal vergimiz, ekonomik bünyemizin gelişmesine ayak uyduramaz hale gelmişstir.

Diğer vergilerden bir kısmı satış vergileri sistemini ve piyasada rekabet düzenini bozmuş bulunmaktadır. Katma Değer vergisini uyguyan ülkelerde bütün ithalat vergiye tabi olduğu halde, bizim istihsal vergimizde, pek çok mallar istihsal vergisine tabi olmadan ithal edilebilmektedir. $\mathrm{Bu}$ nedenle ithalata bazı hallerde diğer ülkelerden daha çok taviz verilmiştir.

Katma Değer Vergisine geçildiğinde, istihsal vergisi, işletme Vergisi, spor toto vergisi, nakliyet vergisı, PTT hizmetleri vergisi, gibi vergiler ilga edilecektir. Ayrıca inşaat, Taşıt alım vergilerinin Katma Değer vergi sistemine uydurulması gereklidir.

Sistemin böylece, mükellefin karşılaştığı pek çok vergi, yerine bir tek vergiye dayalı, kendi kendini kontrol eden yayilı bir hale getirilmesi Türkiyede Gelir ve Emlâk Vergileri reformundan sonra gider vergileri alanında yapilacak en büyük vergi reformu olacaktır.

Bu reform Türkiyeye neler sağhyacaktır. Bu soruyu özetle şu şekilde cevaplandırabiliriz:

1) İstihsal vergisinin mahzurları bertaraf edilecektir.

$\mathrm{Bu}$ gün için istihsal vergisi esas itibariyle ilk istihsal maddelerini vergileyen, bu nedenle yatırımlanı engelleyen, tüketici yönünden tersine müterakki, ilk madde indirimi dolayısı ile bazan idare bazan da mükellef aleyhine işleyen uygulaması teknik bakımından güç bir vergi haline gelmiştir.

2) Vergi sistemimiz dikey ve yatay olarak yayılı hale gelecektir. Geniş tabanlı ve yayılı bir vergi, verginin otomatik etkenliğini ve ekonomide politika aracı ilarak kullanılma olanağını artıracaktır.

3) Katma Değer vergisi bünyesinde taşıdığı oto-kontrol mekanizması sebebiyle tüm vergilerin özellikle gelir vergisinin randumanını artıracaktır. Vergi kaçakcılığı azalacaktır.

4) Hazineye devamlı gelir gelecek ve hazine muamelelerinin ve para politikasının idaresi kolaylaşacaktır.

5) Yatırım ve teknoloji gerçek anlamda teşvik edilmiş olacak, mal stoklaması gibi spekülasyonlar güçleşecektir.

6) Verginin tarafsız olması nedeni ile gerek dahili gerekse milletler arası ticarette serbest piyasa mekanizmasının normal işlemesini güçleştirren engeller kalkmıs olacaktır. Ortak pazar Katma protokolü gereği güm- 
rüklerde yapılan indirimler ve istihsal vergisinin ithalde pek çok malı kapsamına almaması nedeni ile bu gün için rekabet şartları, yerli müteşebbislerimiz aleyhine esasen bozulmuş bulunmaktadır.

7) Katma Değer Vergisi, ihracatta gerçek vergi iadesi yapılması olanağını sağlıyacak, vergi iadesi uygulaması son derece basitleşecektir.

8) Katma Değer vergisinin bütün dünyada son derece revaç bulmasının nedenlerinden bir kaçını, Türkiye açısından yukarıda belirtmiş olduk. Bunlara daha başkaları da eklenebilir.

Türk Vergi sisteminin özellikle satış vergileri alanında, bir reforma muhtaç olduğu bir gerçektir. Bu reformun esas yönü plân ve proğramlarda ve son III. 5 yillık plânda da belirtildiği üzere, Katma Değer vergisidir. Vergi sisteminde yapılacak geliştirmelerle birlikte vergi idaresinin geliştirilmesi gereği de tabii bir sonuç olarak meydana çıkmaktadır. Bu alanda bir an önce yapilacak çabalar ise semeresini verecek niteliktedir. Zira bir ülkede kamu idaresinin düzgün işlemesi, her şeyden önce, o ülkenin sağlam bir Maliye,si olmasına bağlıdır. Sağlam bir maliye politikasının temeli ise vergidir. Ulke gerçeklerine ve kalkınma hedeflerine ve stratejsine uygun bir vergileme olmaksızın ülkenin Bütçe, Hazine, para, yatırım, hatta fiat ve döviz politikasının düzgün işlemesine imkan yoktur.

Katma Değer Vergisine geçişle, vergi sisteminde ve vergi idaresini iyileştirme yönünde yapılacak bir reform, bu yönlerden de son derece önem arzetmektedir.

Numan Özsoy 